\title{
The enigma of the dog mummy from Ancient Egypt and the origin of 'Rhipicephalus sanguineus'
}

\author{
Domenico Otranto ${ }^{1 *}$, Jean-Bernard Huchet ${ }^{2}$, Alessio Giannelli ${ }^{1}$, Cecile Callou ${ }^{2}$ and Filipe Dantas-Torres ${ }^{1,3}$
}

\begin{abstract}
Background: Ticks belonging to the Rhipicephalus sanguineus group are amongst the most important vectors of pathogenic microorganisms to dogs and humans. However, the taxonomy of this species group is still the subject of debate, especially because there is no type specimen or reliable morphological description for Rhipicephalus sanguineus sensu stricto. Recently, a comprehensive morphological and genetic study on representative tick specimens from Europe, Africa, Americas, and Oceania, revealed the existence of at least four morphologically and genetically distinct species under the name ' $R$. sanguineus' infesting dogs from different countries.

Methods: Herein, we examined morphologically tick specimens retrieved on a dog mummy from Ancient Egypt (ca. $1^{\text {st }}$ century $-4^{\text {th }}$ century A.D.). The dog mummy and associated ticks were found during an archaeological expedition conducted in El Deir.
\end{abstract}

Results: Scanning electron micrographs allowed us to assess their identity as belonging to the $R$. sanguineus group. In addition on the basis of the scutal punctation pattern, spiracular plates, width of dorsal tail of spiracular plates relative to the adjacent festoon, female genital aperture, male adanal plates and accessory shields, these ticks were tentatively identified as Rhipicephalus sp. II (=temperate species).

Conclusions: It can be concluded that $R$. sanguineus group ticks have infested dogs living in the Mediterranean region since ancient times. This finding represents the oldest record of ticks on any animal species and adds a new piece in the complex puzzle regarding tick parasitism on dogs and humans and their role as vectors of pathogens.

Keywords: Tick, Rhipicephalus sanguineus, Dog mummy, Archeoparasitology, Origins

\section{Background}

Among domestic animals, dogs have always been alongside humans while hunting, migrating around the globe, and even while exploring the moon. Indeed, for their devotion to their owners and friendly behaviour, dogs have represented the most common pet for humankind throughout their history. Meanwhile, as good friends, dogs share many things with humans, including zoonotic endo- and ecto-parasites [1,2]. Amongst the arthropod parasites of both dogs and humans, the brown dog tick Rhipicephalus sanguineus (Latreille, 1806) is an efficient vector of a diverse group of pathogens [3]. However, in spite of being well-studied, the taxonomy of $R$. sanguineus is largely debated among scientists, because there is no

\footnotetext{
* Correspondence: domenico.otranto@uniba.it

${ }^{1}$ Department of Veterinary Medicine, University of Bari, Valenzano, Bari, Italy

Full list of author information is available at the end of the article
}

type specimen or reliable morphological description for this species [4]. Therefore, while $R$. sanguineus could be regarded as a nomen nudum, this tick is still listed as a valid taxon [5].

During the last century, $R$. sanguineus was placed in synonymy with many species [6,7], whereas others, morphologically similar, were described and ranked within the so-called $R$. sanguineus group, whose definition and number of species is also arguable [7-9]. Several authors have endeavoured to study this group of ticks using both morphological and molecular tools [4,10-16]. Recently, a comprehensive study was undertaken on representative tick specimens belonging to the $R$. sanguineus group from 17 countries in Europe, Africa, Americas, and Oceania [4]. Morphological and molecular analyses revealed the existence of at least four integrated operational taxonomic units (i.e., $R$. sanguineus sensu lato, 
Rhipicephalus sp. I, Rhipicephalus sp. II, and Rhipicephalus sp. III) under the name ' $R$. sanguineus' [4]. Nonetheless, in the absence of a consensus on the identity of $R$. sanguineus sensu stricto, the taxonomical status and actual distribution of these species remains enigmatic.

As for any investigational research, parasitologists need to look for any clue (e.g., morphological, molecular, biological, ecological evidence) to address their questions or hypotheses. Of great interest is to understand when and how parasites developed in animal and human populations. Under these circumstances, archeoparasitology not only investigates the causes of the death of the hosts infected by parasites [17], but also how they moved from one area to another, along with animals and humans during historical migrations [18]. Oddly enough, studies in the field of archeoparasitology have been mainly focussed on protozoa and helminths in coprolites, intestinal contents or latrine deposits [19-23]. In contrast, despite the tough chitinous exoskeleton of arthropods, a relatively low number of archaeoparasitological surveys are available for ectoparasites [24-29], probably because of their location on the host coat, therefore more exposed to the outdoor environment. In addition, archeoparasitological studies on pets are limited to the retrieval of lice from cats [30] and dogs [28,31]. To the best of our knowledge, the only possible iconographic illustration of ticks from Ancient Egypt is constituted by a tomb painting from ancient Thebes (Dra Abu el-Naga, Western Thebes, ca. 1473-1458 B.C.), which displays a hyaena-like animal with excrescences within the ear that were supposed to be ticks [32].

The recent finding of well-mummified dogs from Ancient Egypt in an archaeological expedition conducted in El Deir led to the retrieval of some specimens of ixodid ticks and louse flies on a young dog [33]. Considering the current debate on the taxonomy of this tick species, we decided to carefully re-examine these ticks morphologically, using scanning electron micrographs to assess whether they fit with any of the species illustrated in ref. 4 .

\section{Methods}

The dog mummy was found in a tomb surrounding a Roman fortress in El Deir [33]. This archaeological site, located $30 \mathrm{~km}$ northeast of the town of Kharga (Kharga Oasis, Egypt) at the bottom of Gebel Umm el Ghanayim, has been excavated since 1988 [34-37] in an area including an important agricultural inhabited region, which existed at least from the Ptolemaic period (332-30 B.C.). The necropolises are dated back to a period from the $4^{\text {th }}$ century B.C. to the $5^{\text {th }}$ century A.D. Although this ancient village has not been precisely located, a number of tombs were spread over this area, and, most of them were spoiled over the centuries.

Some anatomical investigations were conducted on many rests of dogs [38], but the mummy of a young dog from tomb P5 was the only well preserved specimen. This mummy displayed a massive infestation by ectoparasites with 61 ticks found firmly attached to the animal coat, mostly in the right ear. Additionally, a single specimen of the louse fly Hippobosca longipennis, as well as more than two hundred puparia of sarcosaprophagous flies of the families Sarcophagidae and Calliphoridae, were also identified (for more details, see ref. 33).

Of the 61 ticks collected, only five specimens (i.e., three males and two females) were better preserved and therefore herein morphologically studied. Ticks were examined at El Deir archaeological site, using a portable scanning electron microscope (SEM) (Nikon JCM-5000, JEOL NeoScope at $10 \mathrm{kV}$ ), without metallization (metal coating). Micrographs were taken from the five specimens and several characters (see below) were examined and/or measured.

All images were carefully evaluated and taxonomically relevant characters for the differentiation of ticks belonging to the $R$. sanguineus group $[4,8,39]$ assessed. In particular, the following characters were studied: idiosoma, dorsal scutum, angles of basis capituli, female porose areas, female genital opening, spiracular plates, lateral and postmediam grooves, cervical pits, cervical fields, internal and external cervical margins, marginal lines, male adanal plates, accessory plates, and male caudal process. Measurements were not taken due to the low number of specimens available and their preservation status. Moreover, no tick specimen or parts of it were available for molecular analysis.

\section{Results}

All ticks were unengorged except for one female, and they were identified as belonging to the genus Rhipicephalus, based on the following general characters: eyes present, anal groove posterior to anus, basis capituli hexagonal in shape, palpi short, coxae I deeply cleft, spiracular plates comma-shaped, and male adanal plates and accessory shields present.

Males presented the following characters: small punctations scattered over the posterior portion of dorsal scutum; larger punctations on the scapular region; marginal groove deep and marked by medium-size punctations (Figure 1A); posteromedian groove distinctly elongated; lateral grooves circular in shape; spiracular plates elongated, and with a narrow dorsal tail (less than half of the adjacent festoon) (Figure 1B); adanal plates large at basis (not sickle-shaped); accessory shields sharply pointed (Figure 1C); caudal process present; posteromedian spur on coxa I longer than the posterolateral spur; angles of basis capituli in anterior third of its length (Figure 1D).

Females presented the following characters: dorsal scutum shield-shaped, with sinuous posterior margin (Figure 2A); outer edge of cervical grooves clearly defined either by 

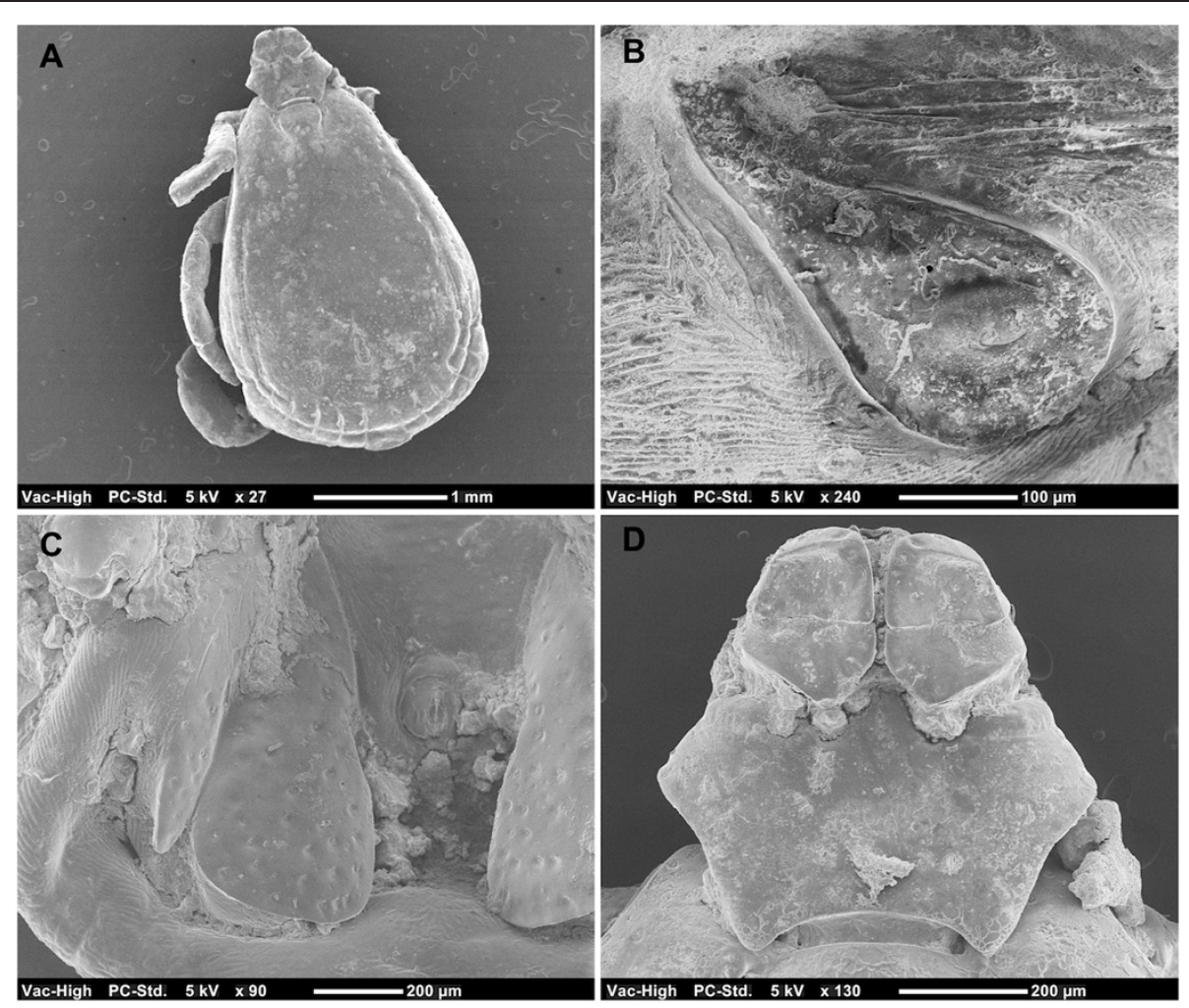

Figure 1 Rhipicephalus sanguineus group male. Dorsal scutum with small punctations scattered over the posterior portion and larger punctations on the scapular region (A); spiracular plate with narrow dorsal tail (B); adanal plate large at base and accessory shield sharply pointed (C); basis capituli hexagonal), dorsal view (D).

slope or punctations; dorsal tail of spiracular plate narrow (Figure 2B); genital aperture broadly U-shaped (Figure 2C); posteromedian spur on coxa I longer than the posterolateral spur; angles of basis capituli at about mid-length; porose areas small, rounded and well separated (Figure 2D).

Based on these key characters, all ticks were identified as belonging to the $R$. sanguineus group. Furthermore, on the basis of the scutal punctation pattern, spiracular plates, width of dorsal tail of spiracular plates relative to the adjacent festoon, female genital aperture, male adanal plates and accessory shields, these ticks were identified as $R$. sp. II (=temperate species) (Figures 1 and 2).

\section{Discussion}

The present study, based on a detailed morphological examination of ticks found on a dog mummy from Ancient Egypt, confirms that they belong to the genus Rhipicephalus. Nonetheless, the actual specific identity of these ticks is difficult to assess, mainly because of the limited number of specimens available and because of their conservation status. However, ticks herein examined were not Rhipicephalus turanicus or R. sp. III, due to the differences in scutal punctation pattern, spiracular plates and/or female genital aperture [4]. Indeed, these ticks resembled those of $R$. sanguineus sensu lato, and some specific morphological characters (e.g., female genital aperture, male adanal plates and accessory shields, scutal punctation pattern and spiracular plates of both males and females) allowed us to tentatively identify those ticks as $R$. sp. II (=temperate species or southern lineage) [4].

The high intensity of tick infestation found on this young mummified dog, along with the absence of any apparent trauma [33], may suggest that the cause of his death could be related to this massive ectoparasite infestation and/or to the infection by tick-borne pathogens. Indeed, $R$. sanguineus group ticks have been implicated as a vector of a wide range of pathogenic microorganisms to dogs (e.g., Babesia vogeli, Ehrlichia canis, Hepatozoon canis and Rickettsia conorii) some of which have zoonotic potential $[3,40]$. In spite of their long co-evolution with their hosts, tick-borne pathogens may cause severe disease and, eventually, the death of infected animals [41]. The dog's death could also be attributed to a more virulent pathogen strain circulating in Ancient Egypt. For instance, although Anaplasma platys is often considered as a less pathogenic organism in dogs [42], virulent strains have also been associated to severe clinical disease in Israel [43]. Tick-borne pathogens commonly cause more severe disease in young individuals at their first exposure [44]. Furthermore, the sequential or simultaneous infection 

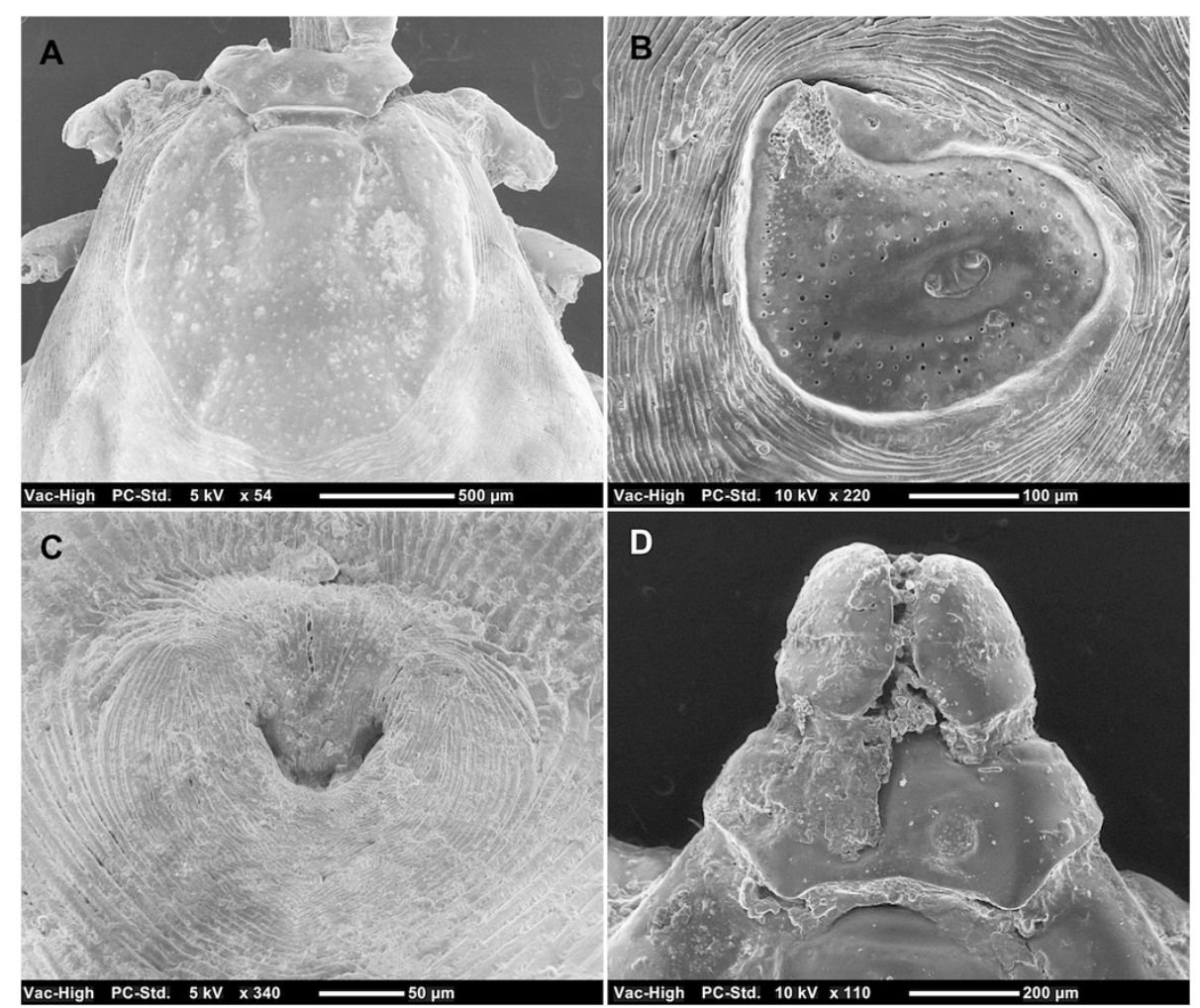

Figure 2 Rhipicephalus sanguineus group female. Dorsal scutum shield-shaped, with sinuous posterior margin (A); spiracular plate with narrow dorsal tail (B); genital aperture broadly U-shaped (C); basis capituli hexagonal, dorsal view (D).

with more than one tick-borne pathogen may also result in the exacerbation of clinical signs and potentiation of haematological abnormalities [45]. This was recently demonstrated in young dogs coinfected with B. vogeli and A. platys, in which more severe clinical and haematological alterations were eventually recorded than in dogs with $B$. vogeli only [46]. Another possible explanation for the death of the young mummified dog could be a fatal paralytic syndrome associated with massive tick infestation. Indeed, a recent study reported neurological signs in 14 young dogs heavily infested by $R$. sanguineus group ticks, ten of which died from this condition and presented neurological signs of different degrees [47].

Although it was not possible to carry out any further parasitological investigation on other dog mummies due to their poor condition, the high number of ticks found on the studied specimen suggests that other animals were also infested. This might have been the cause of an epidemic of tick-borne disease leading to the death of many young animals. Unfortunately, the unavailability of material of ticks for molecular processing and detection of pathogens does not allow us to bring these hypotheses from the realm of speculations to reality. In the same way, the possibility that the dog died due to a viral infectious disease (common cause of sudden death in puppies) cannot be ruled out.
The so-called temperate species $(=R$. sp. II $)$ is widespread in Mediterranean countries, such as France, Portugal, Spain and Italy [4]. Accordingly, our finding might indicate that this tick species has been present for a long time in Egypt. However, the discovery of a tickinfested dog mummy in a tomb surrounding a Roman fortress raises interesting questions on the origin of this dog and his ticks. During the Roman Empire and its colonization, which started about 270 B.C., the Mediterranean area was a theatre for relevant historical events and a hub of different cultures as well as the final destination for several populations. The intense waves of migration occurring before, during and after the Roman Empire could have contributed to the dissemination of dog ticks throughout the Mediterranean region. Indeed, the Roman Empire expanded for more than 400 years through Eurasia (from 275 B.C. to 117 A.D.) and, at its greatest extent, it colonized all the countries touching the Mediterranean sea as far as Germany and Britain (north), Turkey, Lebanon, Iran and Arabia (east) until the split in Eastern and Western sections (395 A.D.). On the other hand, because Rhipicephalus is typically an African tick genus, the most probable hypothesis is that $R$. sanguineus group ticks were introduced into Europe at a certain point of time, most probably with people 
from North Africa, soon after the collapse of the Roman Empire.

\section{Conclusion}

The history of tick species threatening dog and human health often crosses with those of the hosts they parasitize as a part of the everyday existence of individual animals everywhere and in every time. Whether the retrieval of ticks on a mummified young dog, which succumbed around 2,500 years ago due to an obscure illness, can contribute to a better understanding of the $R$. sanguineus group or not is uncertain. Certainly, it adds a new piece in the complex puzzle regarding tick parasitism on dogs and their role as vectors of pathogens to dogs and humans.

\section{Competing interests}

The authors declare that they have no competing interests.

\section{Authors' contributions}

DO and FD-T conceived the research and wrote the first draft. JBH and CC examined the dog mummy, collected the tick specimens and performed the SEM photos. FD-T, DO, and AG did the morphological study. All authors read and approved the final version of the manuscript, contributed with interpretation and revision of the manuscript.

\section{Acknowledgments}

Authors thank Bayer Animal Health for supporting the publications costs. Jean-Bernard Huchet and Cécile Callou are indebted to Françoise Dunand and Roger Lichtenberg (University of Strasbourg, France), heads of the French archeological mission at El Deir site and to Michel Lemoine (UMR 7209 "Archéozoologie, Archéobotanique, MNHN, France) for his precious help regarding the SEM photographs of the archaeological samples. This study was conducted under the frame of the EurNegVec COST Action TD1303.

\section{Author details}

'Department of Veterinary Medicine, University of Bari, Valenzano, Bari, Italy. 2UMR 7209 du CNRS, Archéozoologie, Archéobotanique, Muséum National d'Histoire Naturelle, Paris, France. ${ }^{3}$ Department of Immunology, Aggeu Magalhães Research Centre, Oswaldo Cruz Foundation, Recife, Pernambuco 50670420, Brazil.

Received: 6 December 2013 Accepted: 21 December 2013 Published: 20 January 2014

\section{References}

1. Dantas-Torres F, Otranto D: Dogs, cats, parasites, and humans in Brazil: opening the black box. Parasit Vectors, in press.

2. Otranto D, Dantas-Torres F, Brianti E, Traversa D, Petrić D, Genchi C, Capelli G: Vector-borne helminths of dogs and humans in Europe. Parasit Vectors 2013, 6:16.

3. Dantas-Torres F, Chomel BB, Otranto D: Ticks and tick-borne diseases: a One Health perspective. Trends Parasitol 2012, 28:437-446.

4. Dantas-Torres F, Latrofa MS, Annoscia G, Giannelli A, Parisi A, Otranto D: Morphological and genetic diversity of Rhipicephalus sanguineus sensu lato from the New and Old Worlds. Parasit Vectors 2013, 6:213.

5. Guglielmone AA, Robbins RG, Apanaskevich DA, Petney TN, Estrada-Peña A, Horak IG: Comments on controversial tick (Acari: Ixodida) species names and species described or resurrected from 2003 to 2008. Exp Appl Acarol 2009, 48:311-327.

6. Neumann LG: Ixodidae. Berlin: Das Tierreich; 1911

7. Camicas JL, Hervy JP, Adam F, Morel PC: Les tiques du monde. Nomenclature, stades décrits, hôtes, répartition (Acarida, Ixodida). Paris: Éditions de I'Orstom; 1998.

8. Walker JB, Keirans JE, Horak IG: The Genus Rhipicephalus (Acari, Ixoidae). A Guide to the Brown Ticks of the World. Cambridge, UK: Cambridge Univ. Press; 2000.
9. Gray J, Dantas-Torres F, Estrada-Peña A, Levin M: Systematics and ecology of the brown dog tick, Rhipicephalus sanguineus. Ticks Tick Borne Dis 2013, 4:171-180.

10. Oliveira PR, Bechara GH, Denardi SE, Saito KC, Nunes ET, Szabó MP, Mathias MI: Comparison of the external morphology of Rhipicephalus sanguineus (Latreille, 1806) (Acari: Ixodidae) ticks from Brazil and Argentina. Vet Parasitol 2005, 129:139-147.

11. Szabó MP, Mangold AJ, João CF, Bechara GH, Guglielmone AA: Biological and DNA evidence of two dissimilar populations of the Rhipicephalus sanguineus tick group (Acari: Ixodidae) in South America. Vet Parasitol 2005, 130:131-140

12. Burlini L, Teixeira KR, Szabó MP, Famadas KM: Molecular dissimilarities of Rhipicephalus sanguineus (Acari: Ixodidae) in Brazil and its relation with samples throughout the world: is there a geographical pattern? Exp App/ Acarol 2010, 50:361-374.

13. Moraes-Filho J, Marcili A, Nieri-Bastos FA, Richtzenhain LJ, Labruna MB: Genetic analysis of ticks belonging to the Rhipicephalus sanguineus group in Latin America. Acta Trop 2011, 117:51-55.

14. Levin ML, Studer E, Killmaster L, Zemtsova G, Mumcuoglu KY: Crossbreeding between different geographical populations of the brown dog tick, Rhipicephalus sanguineus (Acari: Ixodidae). Exp Appl Acarol 2012, 58:51-68.

15. Nava S, Mastropaolo M, Venzal JM, Mangold AJ, Guglielmone AA: Mitochondrial DNA analysis of Rhipicephalus sanguineus sensu lato (Acari: Ixodidae) in the Southern Cone of South America. Vet Parasitol 2012, 190:547-555

16. Latrofa MS, Dantas-Torres F, Annoscia G, Cantacessi C, Otranto D: Comparative analyses of mitochondrial and nuclear genetic markers for the molecular identification of Rhipicephalus spp. Infect Genet Evol 2013, 20C:422-427.

17. Reinhard KJ: Archaeoparasitology in North America. Am J Phys Anthropol 1990, 82:145-163.

18. Otranto D, Stevens JR, Brianti E, Dorchies P: Human and livestock migrations: a history of bot fly biodiversity in the Mediterranean region. Trends Parasitol 2006, 22:209-213.

19. Fry GF: Analysis of fecal material. In The Analysis of Prehistoric Diets. Edited by Gilbert RI Jr, Mielke J. Orlando: Academic Press; 1985:127-154.

20. Reinhard KJ, Confalonieri UE, Herrmann B, Ferreira LF, Araujo AJG: Recovery of parasite eggs from coprolites and latrines: aspects of paleoparasitological technique. Homo 1998, 37:217-239.

21. Gonçalves MLC, Araujon A, Ferreira LF: Human intestinal parasites in the past: new findings and a review. Mem Inst Oswaldo Cruz 2003, 98:103-118.

22. Bouchet $F$, Harter $S$, Le Bailly $M$ : The state of the art of paleoparasitological research in the old world. Mem Inst Oswaldo Cruz 2003, 98:95-101.

23. Araújo $A$, Reinhard $K$, Leles $D$, Sianto $L$, Iñiguez $A$, Fugassa $M$, Arriaza $B$, Orellana N, Ferreira LF: Paleoepidemiology of intestinal parasites and lice in pre-Columbian America. Rev Chil Hist Nat 2001, 43:303-313.

24. Capasso L, Di Tota G: Lice buried under the ashes of Herculaneum. Lancet 1998, 351:992.

25. Yvinec $\mathrm{JH}$, Ponel $\mathrm{P}$, Beaucournu $\mathrm{JC}$ : Premiers apports archéoentomologiques de l'étude des Puces, Aspects historiques et anthropologiques (Siphonaptera). Bull Soc Ent Fr 2000, 105:419-425.

26. Rick FM, Rocha GC, Dittmar K, CoimbraX CE Jr, Reinhard K, Bouchet F, Ferreira LF, Araujo A: Crab louse infestation in pre-Columbian America. J Parasitol 2002, 88:1266-1267.

27. Guerra RMSNC, Gazeta GS, Amorim M, Duarte AN, Serra-Freire NM: Ecological analysis of acari recovered from coprolites from archaeological site of northeast Brazil. Mem Inst Oswaldo Cruz 2003, 98:181-190.

28. Dittmar K, Mamat U, Whiting M, Goldmann T, Reinhard K, Guillen S: Techniques of DNA-studies on Prehispanic Ectoparasites (Pulex sp., Pulicidae, Siphonaptera) from animal mummies of the Chiribaya culture, Southern Peru. Mem Inst Oswaldo Cruz 2003, 98:53-58.

29. Reinhard KJ, Buikstra J: Louse infestation of the Chiribaya culture, Southern Peru: variation in prevalence by age and sex. Mem Inst Oswaldo Cruz 2003, 98:173-179.

30. Guerra RMSNC, Duarte AN, Oliveira HH, Mello RP, Serra-Freire NM: The finding of Felicola felis (Mallophaga: Trichodectidae) and exuviae of Amblycera in Felidae coprolites from the archaeological site of Furna do Estrago, Pernambuco state, Brazil. Entomol Vect 2001, 8:395-402.

31. Martinson E, Reinhard K, Buikstra JE, Dittmar de la Cruz K: Pathoecology of Chiribaya Parasitism. Mem Inst Oswaldo Cruz 2003, 98:195-205.

32. Arthur DR: Ticks in Egypt in 1500 B.C.? Nature 1965, 206:1060-1061 
33. Huchet JB, Callou C, Lichtentberg R, Dunand F: The dog mummy, the ticks and the louse fly: archaeological report of a severe ectoparasitosis in Ancient Egypt. Int J Paleopathol 2013, 3:165-175.

34. Dunand F, Lichtenberg R: Dix ans d'exploration des nécropoles d'El-Deir (oasis de Kharga). Un premier bilan. Chron Egypte 2008, 83:258-288.

35. Dunand F, Coudert M, Letellier-Willemin F: Decouverte d'une nécropole chrétienne sur le site d'El-Deir (oasis de Kharga). In Etudes coptes X, Douzième journée d'études (Lyon, 19-21 mai 2005). Edited by Cahiers de la Bibliothèque copte. Paris: Boud'hors A and Louis C; 2008:137-155.

36. Dunand F, Heim JL, Lichtenberg R, Brones S, Devaux E, Dussarps L, Letellier-Willemin F, Tallet G: El-Deir Nécropoles II. Les Nécropoles Nord et Nord-Est. Paris: Cybèle; 2012.

37. Dunand F, Heim JL, Lichtenberg R, Brones S, Letellier-Willemin F: El-Deir Nécropoles I. La Nécropole Sud. Paris: Cybèle; 2010.

38. Callou C, Dunand F, Lichtenberg R: In Archaeological and Archaeozoological Study of Dogs from El-Deir. Edited by PalArch's J Archaeol. Egypt/Egyptol. Cairo, Egypt: Proceeding of International meeting of The Bioarchaeology of Ancient Egypt; 2013:10.

39. Filippova NA: Fauna of Russia and Neighbouring Countries. Ixodid Ticks of Subfamily Amblyomminae. Moscow, Russia: Nauka Publishing House; 1997:436.

40. Dantas-Torres F: The brown dog tick, Rhipicephalus sanguineus (Latreille, 1806) (Acari: Ixodidae): from taxonomy to control. Vet Parasitol 2008, 152:173-185.

41. Otranto D, Dantas-Torres F, Breitschwerdt EB: Managing canine vectorborne diseases of zoonotic concern: part two. Trends Parasitol 2009, 25:228-235.

42. Bradfield JF, Vore SJ, Pryor WH Jr: Ehrlichia platys infection in dogs. Lab Anim Sci 1996, 46:565-568.

43. Harrus S, Aroch I, Lavy E, Bark H: Clinical manifestations of infectious canine cyclic thrombocytopenia. Vet Rec 1997, 141:247-250.

44. Kontos VJ, Koutinas AF: Clinical observations in 15 spontaneous cases of canine babesiosis. Canine Practice 1997, 22:30-34.

45. Kordick SK, Breitschwerdt EB, Hegarty BC, Southwick KL, Colitz CM, Hancock SI, Bradley JM, Rumbough R, Mcpherson JT, MacCormack JN: Coinfection with multiple tick-borne pathogens in a Walker Hound kennel in North Carolina. J Clin Microbiol 1999, 37:2631-2638.

46. de Caprariis D, Dantas-Torres F, Capelli G, Mencke N, Stanneck D, Breitschwerdt $E B$, Otranto D: Evolution of clinical, haematological and biochemical findings in young dogs naturally infected by vector-borne pathogens. Vet Microbiol 2011, 149:206-212.

47. Otranto D, Dantas-Torres F, Tarallo VD, Ramos RA, Stanneck D, Baneth G, de Caprariis D: Apparent tick paralysis by Rhipicephalus sanguineus (Acari: Ixodidae) in dogs. Vet Parasitol 2012, 188:325-329.

doi:10.1186/1756-3305-7-2

Cite this article as: Otranto et al:: The enigma of the dog mummy from Ancient Egypt and the origin of 'Rhipicephalus sanguineus'. Parasites \& Vectors 2014 7:2.

\section{Submit your next manuscript to BioMed Central and take full advantage of:}

- Convenient online submission

- Thorough peer review

- No space constraints or color figure charges

- Immediate publication on acceptance

- Inclusion in PubMed, CAS, Scopus and Google Scholar

- Research which is freely available for redistribution

Submit your manuscript at www.biomedcentral.com/submit
C Biomed Central 